\title{
Zika virus detection in urine from patients with Guillain-Barré syndrome on Martinique, January 2016
}

B Rozé ${ }^{1}$, F Najioullah ${ }^{23}$, J Fergé ${ }^{4}$, K Apetse ${ }^{5}$, Y Brouste $^{6}$, R Cesaire $^{23}$, C Fagour 7 , L Fagour ${ }^{2}$, P Hochedez ${ }^{13}$, Jeannin $^{8}$, J

Joux $^{8}$, H Mehdaoui ${ }^{4}$, R Valentino ${ }^{4}$, A Signate ${ }^{8}$, A Cabié ${ }^{139}$, on behalf of the GBS Zika Working Group ${ }^{10}$

1. Infectious and Tropical diseases Unit, Universitary Hospital of Martinique, Fort de France, France

2. Laboratory of Virology, Universitary Hospital of Martinique, Fort de France, France

3. Université des Antilles, EA4537, Fort de France, France

4. Intensive Care Unit, Universitary Hospital of Martinique, Fort de France, France

5. Electrophysiological Departement, Universitary Hospital of Martinique, Fort de France, France

6. Emergency Departement, Universitary Hospital of Martinique, Fort de France, France

7. Diabetology Departement, Universitary Hospital of Martinique, Fort de France, France

8. Neurology Departement, Universitary Hospital of Martinique, Fort de France, France

9. INSERM CIC1428, Fort de France, France

10. The members of the group are listed at the end of the article

Correspondence: Benoît Rozé (benoit.roze@chu-fortdefrance.fr)

Citation style for this article:

Rozé B, Najioullah F, Fergé J, Apetse K, Brouste Y, Cesaire R, Fagour C, Fagour L, Hochedez P, Jeannin S, Joux J, Mehdaoui H, Valentino R, Signate A, Cabié A, on behalf of the GBS Zika Working Group. Zika virus detection in urine from patients with Guillain-Barré syndrome on Martinique, January 2016 . Euro Surveill. 2016;21(9):pii=30154. DOI: http://dx.doi.org/10.2807/1560-7917.ES.2016.21.9.30154

We report two cases of Guillain-Barré syndrome who had concomitant Zika virus viruria. This viruria persisted for longer than 15 days after symptom onset. The cases occurred on Martinique in January 2016, at the beginning of the Zika virus outbreak. Awareness of this possible neurological complication of ZikV infection is needed.

Two cases of Guillain-Barré syndrome (GBS) were diagnosed in January 2016 on Martinique, a French West Indies island of 390,000 inhabitants. Both patients were found to have ZikV in their urine at hospital admission. An outbreak of Zika virus (ZikV) infections has been ongoing on the island since December 2015 [1] and spread rapidly, with more than 1,000 estimated cases per week in 2016 [2].

ZikV infection is usually benign, when symptomatic. The disease is a dengue-like syndrome, characterised by fever, headache, retro-orbital pain, non-purulent conjunctivitis, maculopapular rash, arthralgia, and myalgia. The symptoms last for four to seven days and are self-limiting. Recent ZikV epidemics in French Polynesia, Brazil and Central America have been associated with Guillain-Barré syndrome (GBS) outbreaks, the probable link between these two diseases was made based on serological and anamnestic data [3-6].

\section{Case description}

Case 1

In the first week of January, four weeks after the detection of the first ZikV-positive cases on Martinique, a young adult complaining of gait disturbance was admitted to the University Hospital of Martinique. In the week before admission, the patient had felt numbness in their four extremities followed by constipation. There was no history of infectious respiratory symptoms, diarrhoea or recent arboviral infection. At first clinical evaluation, the patient had a flaccid tetraparesis, with asymmetric peripheral facial palsy and deglutition disorders (without oculomotor disturbance or ataxia). Intravenous polyvalent immunoglobulin (IVIg) ( $0.4 \mathrm{~g} / \mathrm{kg} /$ day for five days) was administered, starting on the first day of admission. However, the neurological disorders worsened and two days later, due to paralysis of the respiratory musculature leading to respiratory failure, the patient needed mechanical ventilation. The patient recovered autonomous ventilation after seven days of intensive care, where they were hospitalised for a total of 10 days. The patient is currently in the rehabilitation unit of the University Hospital.

Electromyography (EMG) and nerve conduction studies were performed on day 15 after onset of neurological symptoms. There were abnormal sensory nerve action potentials with sural sparing pattern. Motor abnormalities were consistent with demyelination (delayed distal latencies, slowed nerve conduction velocity, temporal dispersion of waveforms, some conduction blocks and absent $F$ waves) and the spontaneous needle EMG was normal. Total spinal cord magnetic resonance imaging (MRI) was normal. We did not perform any brain MRI. Blood, cerebrospinal fluid (CSF) and urine samples were taken before the administration of IVIg. Blood analysis showed no biochemical disorders. Blood count was normal except for a white blood cell count of 11,440 cells $/ \mathrm{mL}$ (norm: $4-10$ ). The analysis of CSF 
Microbiological data for two patients with Guillain-Barré syndrome, Martinique, January 2016

\begin{tabular}{|c|c|c|c|}
\hline Microorganism & Detection & Case 1 & Case 2 \\
\hline Campylobacter jejuni & Serology & Ratio<8 $(\mathrm{N}<128)$ & Ratio < $8(\mathrm{~N}<128)$ \\
\hline Campylobacter fetus & Serology & Ratio<8 $(\mathrm{N}<128)$ & Ratio <8 $(\mathrm{N}<128)$ \\
\hline Mycoplasma pneumoniae & Serology & $\begin{array}{l}\lg M<0.8(N<0.8) \\
\lg G<10(N<10)\end{array}$ & $\begin{array}{c}\lg M<0.8(N<0.8) \\
\lg G<10(N<10)\end{array}$ \\
\hline Epstein-Barr virus & Serology & $\begin{array}{c}\text { IgM anti-VCA: } \\
0.14 \mathrm{IU} / \mathrm{mL}(\mathrm{N}<0.9 \mathrm{UI} / \mathrm{ml}) \\
\mathrm{IgG} \text { anti-VCA: } \\
2.42 \mathrm{IU} / \mathrm{mL}(\mathrm{N}<0.9 \mathrm{UI} / \mathrm{ml}) \\
\mathrm{IgG} \text { anti-EBNA: } \\
2.42 \mathrm{IU} / \mathrm{mL}(\mathrm{N}<0.9 \mathrm{UI} / \mathrm{ml})\end{array}$ & $\begin{array}{c}\text { IgM anti-VCA: } \\
\text { I IU/mL }(\mathrm{N}<0.9 \mathrm{UI} / \mathrm{ml}) \\
\operatorname{lgG} \text { anti-VCA: } \\
2.66 \mathrm{IU} / \mathrm{mL}(\mathrm{N}<0.9 \mathrm{UI} / \mathrm{ml}) \\
\mathrm{IgG} \text { anti-EBNA: } \\
2.42 \mathrm{IU} / \mathrm{mL}(\mathrm{N}<0.9 \mathrm{UI} / \mathrm{ml})\end{array}$ \\
\hline Human immunodeficiency virus & Serology & Ratio: $0.23(\mathrm{~N}<0.9)$ & Ratio: $0.15(\mathrm{~N}<0.9)$ \\
\hline Herpes simplex virus & CSF (PCR) & Negative & Negative \\
\hline \multirow[t]{2}{*}{ Cytomegalovirus } & Serology & $\begin{array}{l}\text { Ratio IgM: } 0.22(\mathrm{~N}<0.7) \\
\text { Ratio IgG: } 270(\mathrm{~N}<0.5)\end{array}$ & $\begin{array}{l}\text { Ratio IgM: } 0.19(\mathrm{~N}<0.7) \\
\text { Ratio IgG: } 233(\mathrm{~N}<0.5) \\
\end{array}$ \\
\hline & CSF (PCR) & Negative & Negative \\
\hline Varicella zoster virus & CSF (PCR) & Negative & Negative \\
\hline Enterovirus, incl poliovirus & CSF (RT-PCR) & Negative & Negative \\
\hline \multirow{3}{*}{ Dengue virus } & Serology & $\begin{array}{l}\text { Ratio IgM: } 0.63(\mathrm{~N}<0.9) \\
\text { Ratio IgG: } 6.28(\mathrm{~N}<1.8)\end{array}$ & $\begin{array}{l}\text { Ratio IgM: } 1.24(\mathrm{~N}<0.9) \\
\text { Ratio IgG: } 3.74(\mathrm{~N}<1.8)\end{array}$ \\
\hline & Plasma (RT-PCR) & Negative & Negative \\
\hline & CSF (RT-PCR) & Negative & Negative \\
\hline \multirow{3}{*}{ Chikungunya virus } & Serology & $\begin{array}{l}\text { Ratio IgM: } 0.079(\mathrm{~N}<0.8) \\
\text { Ratio IgG: } 0.136(\mathrm{~N}<0.8)\end{array}$ & $\begin{array}{l}\text { Ratio IgM: } 0.304(\mathrm{~N}<0.8) \\
\text { Ratio IgG: } 2.669(\mathrm{~N}<0.8)\end{array}$ \\
\hline & Plasma (RT-PCR) & Negative & Negative \\
\hline & CSF (RT-PCR) & Negative & Negative \\
\hline \multirow{5}{*}{ Zika virus } & Plasma (RT-PCR) & Negative & Negative \\
\hline & CSF (RT-PCR) & Negative & Negative \\
\hline & Urine $\mathrm{D}^{\mathrm{a}} 5$ (RT-PCR) & Not tested & Positive \\
\hline & Urine D15 (RT-PCR) & Positive & Positive \\
\hline & Urine D21 (RT-PCR) & Negative & Positive \\
\hline
\end{tabular}

CSF: cerebrospinal fluid; EBNA: Eppstein-Barr nuclear antigen; IgG: immunoglobuline G; IgM: immunoglobuline M; IU: international unit; N: normal value; PCR: polymerase chain reaction; RT-PCR: reverse transcription polymerase chain reaction; VCA: viral capsid antigen;

a Day after the onset of the neurological symptoms.

showed an albuminocytological dissociation with 1.50 $\mathrm{g} / \mathrm{L}$ proteins (norm: $0.15-0.40$ ) and a white blood cell count of $4 / \mathrm{mL}$ (norm $<10)$. The glycorachia/glycaemia ratio was normal (norm $>0.5$ ).

The patient was screened for the common aetiologies of GBS: serological tests for Campylobacter jejuni, C. fetus, Mycoplasma pneumoniae and human immunodeficiency virus (HIV) were negative. Direct detection in CSF of herpes simplex virus, varicella zoster virus and cytomegalovirus by PCR were negative. Direct detection of ZikV by RT-PCR in urine gave a positive result on day 15 after onset of neurological symptoms (Table) but was negative in plasma and CSF.

\section{Case 2}

In the third week of January 2016, a person in their $50 \mathrm{~s}$ was admitted to the University Hospital of Martinique complaining of gait disturbance. Numbness of the four extremities and constipation had started three days before admission. The patient had no history of infectious respiratory symptoms, diarrhoea or recent arboviral infection. At first clinical evaluation, flaccid tetraparesis with bilateral asymmetric peripheral facial palsy and signs of respiratory distress were present. IVIg ( $0.4 \mathrm{~g} / \mathrm{kg} /$ day for five days) was promptly administered. On the day after admission, the patient was tetraplegic and paralysis of the respiratory musculature, leading to respiratory failure, necessitated support by mechanical ventilation. The patient was hospitalised in intensive care unit for one month.

EMG and nerve conduction studies were performed on day 10 after onset of neurological symptoms. The results were similar as for Case 1 . There were abnormal sensory nerve action potentials with sural sparing pattern. Motor abnormalities were consistent with demyelination (delayed distal latencies, slowed nerve conduction velocities, temporal dispersion of waveforms, some conduction blocks and absent $F$ waves) and the spontaneous needle EMG was normal. Total spinal cord MRI was normal. We did not perform any 
brain MRI. Blood, CSF and urine samples were taken before the administration of intravenous immunoglobulin. The analysis of CSF showed an albuminocytological dissociation with $0.79 \mathrm{~g} / \mathrm{L}$ protein (norm: $0.15-0.40$ ) and a white blood cell count of $1 / \mathrm{mL}$ (norm <10). The glycorachia/glycaemia ratio (norm >0.5) was normal. The patient was screened for the common aetiologies of GBS: serological tests for Campylobacter jejuni, $C$. fetus, Mycoplasma pneumonia and HIV were negative. Direct detection of herpes simplex virus, varicella zoster virus and cytomegalovirus by PCR in CSF were negative. Direct detection of ZikV by RT-PCR in urine was positive on days 5, 15 and 21 after onset of neurological symptoms. Detailed microbiological results are shown in Table.

\section{Discussion}

We present two typical cases of GBS according to clinical, electrophysiological and lab findings. Laboratory confirmation of ZikV infections is based on the detection of viral RNA in serum by RT-PCR and of IgM against ZikV by enzyme-linked immunosorbent assay (ELISA). This is challenging because viraemia in ZikV-infected patients is short. Furthermore, there is cross-reactivity between ZikV antibodies and antibodies against other flaviviruses (including dengue virus (DENV)) [7]. ZikV antibody specificity can be determined by plaque reduction neutralisation tests [3]; these tests are done by the French National Reference Laboratory for arboviruses in Marseille, France, which is $7,800 \mathrm{~km}$ away from Martinique. All ZikV serology for the University Hospital of Martinique is done in that reference laboratory. The serological results for the two patients are currently pending, which limits this report in that ZikV infection has not yet been confirmed, although we consider the diagnosis to be likely.

Case 2 had a DENV IgM ratio of 1.24 (normal < 0.9). DENVspecific IgM ELISA is an appropriate test for serum specimens collected from day 5 of illness. However, its positive predictive value is limited by potential crossreactivity with other flaviviruses and false positivity due to other pathogens causing acute febrile illness such as leptospirosis or due to past DENV infection [8]. Martinique has experienced several outbreaks of dengue fever since 2001 and, in 2011, a prospective study in adult blood donors reported a $93 \%$ seroprevalence for DENV antibodies [9]. The IgM result for Case 2 could be explained by persistent seropositivity from an older DENV infection or a cross-reaction to a recent ZikV infection.

For dengue, Zika and West Nile virus infections, several authors have demonstrated that RNA is detectable in urine at higher load and for a longer time than in plasma, and proposed that detection of RNA in urine could be used for the diagnosis of these infections $[7,10,11]$. For these reasons, direct RNA identification by RT-PCR in plasma and urine may be a good way to confirm flavivirus infections in populations exposed to Aedes spp. mosquitos.

\section{Conclusion}

This report has introduced two patients with GBS who had concomitant ZikV viruria. However, the detected asymptomatic prolonged excretion may not be related to the neurological symptoms. The average annual incidence of GBS on Martinique is close to eight cases per 390,000 inhabitants (data not shown). An association with ZikV infection has to be confirmed on further cases. Potential physiopathological mechanisms of ZikV-related GBS should be explored.

Viral excretion in urine was longer than 15 days in our patients, whereas RNA detection in blood was negative. We think that ZikV viruria needs to be investigated for a period longer than 15 days after onset of the neurological symptoms in GBS cases. We have to investigate if the genito-urinary compartment is a sanctuary for persistent replication.

\section{GBS Zika Working Group}

Dr Sylvie Abel, Dr Gwenole Jean Abgrall, Dr José-Luis Barnay, Dr Philippe Cabre, Dr Cyrille Chabartier, Dr Christophe Deligny, Dr Nicole Desbois, Dr Anne-Laure Dessoy, Dr Gaëlle Dunoyer, Dr Régis Duvauferrier, Dr Stéphane Gaucher, Dr Sarah Gourgoudou, Dr Gwladys Ivanes, Dr Yolène Jacquens, Dr Armelle Jean-Etienne, Dr Jean-Louis Lamaignère, $\mathrm{Dr}$ Véronique Legris-Allusson, Dr Mehdi Mejdoubi, Dr Corinne Michel, Dr Franck Michel, Dr Charline Miossec, Dr Florence Moinet, Dr Claude Olive, Dr Pascale Olive, Dr Karine Pailla, Dr Céline Paysant, Dr Katlyne Polomat, Dr Sandrine PierreFrançois, Dr Mathilde Pircher, Dr Patrick René-Corail, Dr Dabor Resiere, Dr Christiane Richer, Dr Marie Sabia, Dr Michel Schloesser, Dr Pauline Simonnet-Vigeral, Dr Rafaelle Théodose.

Conflict of interest

None declared.

Authors' contributions

$\mathrm{BR}, \mathrm{FN}, \mathrm{PH}, \mathrm{AC}$ Wrote the manuscript. AS, JF, KA, JJ, SJ, MS, $\mathrm{YB}, \mathrm{HM}, \mathrm{RV}$ and the Zika Working Group took part in the clinical management of the patients. FN, RC Collaborated in molecular biology techniques. LF, RC, FN collaborated on the serological techniques. All authors participated in the outbreak investigation. All authors read and approved the final manuscript.

\section{References}

1. Emergence du virus Zika aux Antilles Guyane. [Outbreak of Zika virus in Antilles Guyane]. Le point épidémiologique, CIRE Antilles Guyane. 2016;1:1-3. French. Available from: http://www.ars.martinique.sante.fr/fileadmin/MARTINIQUE/ Actualites/Autres_actu/2015/ZIKA/Supports_COM/PE_ Zika_2016-1.pdf

2. Emergence du virus Zika aux Antilles Guyane. [Outbreak of Zika virus in Antilles Guyane]. Le point épidémiologique, CIRE Antilles Guyane. 2016;4:1-4. French. Available from: http://www.ars.martinique.sante.fr/fileadmin/MARTINIQUE/ Actualites/Autres_actu/2016/ZIKA/PE/PE_Zika_2016-4.pdf

3. Oehler E, Watrin L, Larre P, Leparc-Goffart I, Lastere S, Valour $\mathrm{F}$, et al. Zika virus infection complicated by Guillain-Barre syndrome--case report, French Polynesia, December 2013. Euro Surveill. 2014;19(9):20720. DOI: 10.2807/1560-7917. ES2014.19.9.20720 PMID: 24626205 
4. Mallet HP, Vial AL, Musso D. Bilan de l'epidemie a virus Zika en Polynesie Francaise, 2013-2014. [Summary of Zika virus epidemiology in French Polynesia 2013-2014]. BISES (Bulletin d'information sanitaires, épidémiologiques et statistiques). 2015;13:1-4. French. Available from: www.hygiene-publique. gov.pf/IMG/pdf/no13_-_mai_2015_-_zika.pdf

5. European Centre for Disease Prevention and Control (ECDC). Zika virus epidemic in the Americas: potential association with microcephaly and Guillain-Barré syndrome - 10 December 2015. Rapid risk assessment. Stockholm: ECDC; 2015. Available from: http://ecdc.europa.eu/ en/publications/Publications/ zika-virus- americas-association-with-microcephaly- rapidrisk-assessment.pdf

6. Cao-Lormeau V, Blake A, Mons $M$, Lastère $S$, Roche $C$, Vanhomwegen J, et al. Guillain-Barré syndrome outbreak associated with Zika virus infection in French Polynesia: a case-control study. The Lancet. 2016. [ePub ahead of print]. http://dx.doi.org/DOI: 10.1016/S0140-6736(16)00562-6

7. Hirayama T, Mizuno Y, Takeshita N, Kotaki A, Tajima S, Omatsu T, et al. Detection of dengue virus genome in urine by real-time reverse transcriptase PCR: a laboratory diagnostic method useful after disappearance of the genome in serum. J Clin Microbiol. 2012;50(6):2047-52. DOI: 10.1128/JCM.06557-11 PMID: 22442323

8. Najioullah F, Combet E, Paturel L, Martial J, Koulmann L, Thomas $L$, et al. Prospective evaluation of nonstructural 1 enzyme-linked immunosorbent assay and rapid immunochromatographic tests to detect dengue virus in patients with acute febrile illness. Diagn Microbiol Infect Dis. 2011;69(2):172-8. DOI: 10.1016/j.diagmicrobio.2010.09.021 PMID: 21251561

9. L'Azou M, Jean-Marie J, Bessaud M, Cabié A, Césaire R, de Lamballerie $X$, et al. Dengue seroprevalence in the French West Indies: a prospective study in adult blood donors. Am J Trop Med Hyg. 2015;92(6):1137-40. DOI: 10.4269/ajtmh.14-0211 PMID: 25846291

10. Gourinat AC, O'Connor O, Calvez E, Goarant C, DupontRouzeyrol M. Detection of Zika virus in urine.Emerg Infect Dis. 2015;21(1):84-6. DOI: 10.3201/eid2101.140894 PMID: 25530324

11. Barzon L, Pacenti M, Franchin E, Pagni S, Martello T, Cattai $M$, et al. Excretion of West Nile virus in urine during acute infection. J Infect Dis. 2013;208(7):1086-92. DOI: 10.1093/ infdis/jit290 PMID: 23821721

\section{License and copyright}

This is an open-access article distributed under the terms of the Creative Commons Attribution (CC BY 4.0) Licence. You may share and adapt the material, but must give appropriate credit to the source, provide a link to the licence, and indicate if changes were made.

This article is copyright of the authors, 2016. 